\title{
Ecophysiological responses of native invasive woody Juniperus virginiana L. to resource availability and stand characteristics in the semiarid grasslands of the Nebraska Sandhills
}

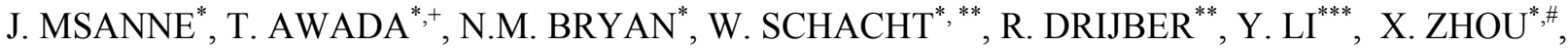 \\ J. OKALEBO*, D. WEDIN*, J. BRANDLE*, and J. HILLER* \\ School of Natural Resources ${ }^{*}$, Department of Agronomy and Horticulture ${ }^{* *}$, University of Nebraska, Lincoln, \\ Nebraska, 68583, USA \\ Cold and Arid Regions Environmental and Engineering Research Institute, Chinese Academy of Sciences, \\ Lanzhou 730000, China ${ }^{* * *}$ \\ Campbell Scientific Inc., Logan, Utah, 84341, USA
}

\begin{abstract}
Vegetation in grasslands is changing at an unprecedented rate. In the Nebraska Sandhills, this shift is attributed in part to encroachment of the woody species Juniperus virginiana. We investigated changes in resource availability and their feedback on seasonal trends in photosynthetic characteristics of $J$. virginiana trees scattered in open grasslands $v s$. a dense 57-year-old stand. Dense stand exhibited lower volumetric soil water content, $\mathrm{NH}_{4}{ }^{+}, \mathrm{NO}_{3}{ }^{-}$, and $\delta^{13} \mathrm{C}$, as well as foliage $\delta^{13} \mathrm{C}, \delta^{15} \mathrm{~N}$, and $\mathrm{N}$ content, compared to grasslands. Water potential was higher in trees in grasslands compared to dense stand. $J$. virginiana in dense stand exhibited similar trends to trees in grasslands for net photosynthetic rate $\left(P_{\mathrm{N}}\right)$, stomatal conductance, transpiration, maximum photochemical efficiency of PSII, maximum carboxylation velocity, and maximum rate of electron transport. $P_{\mathrm{N}}$ peaked early summer and declined in the fall, with trees in open grasslands lagging behind those in dense stand. Plasticity of this species may place it at a competitive advantage in the Sandhills, further altering grasslands vegetation and ecosystem processes.
\end{abstract}

Additional key words: carboxylation velocity; eastern red cedar; electron transport; fluorescence; gas exchange; isotope ratio; soil nutrients.

\section{Introduction}

Vegetation cover in grasslands and savannas and the resulting ecosystem processes are changing at an unprecedented rate across the globe (Archer 1994, Wilcox 2010, Twidwell et al. 2013, Ganguli et al. 2016). This phenomenon has been attributed to climate variability and change, increased carbon dioxide concentrations in the atmosphere, and changes in disturbance fire regimes and anthropogenic management (Wilcox 2010, Diez et al. 2012). Globally, these ecosystems contribute to around $35 \%$ of the terrestrial net primary production (NPP, Chapin et al. 2011), and provide significant agricultural (e.g., livestock) and ecological services (Briggs et al. 2005). Over the past century, grasslands and savannas worldwide have experienced directional and sometimes persistent

Received 26 August 2016, accepted 2 December 2016, published as online-first 15 December 2016.

${ }^{+}$Corresponding author; e-mail: tawada@unl.edu

Abbreviations: $\mathrm{C}-$ carbon; $\mathrm{C}_{\mathrm{i}}-$ intercellular $\mathrm{CO}_{2}$ concentration; $\mathrm{D}$ - vapor pressure deficit between the leaf and air; $\mathrm{DBH}-\mathrm{diameter}$ at breast height; DOY - day of year; $E$ - transpiration; $\mathrm{F}_{0}$ - minimal fluorescence yield of the dark-adapted state; $\mathrm{F}_{\mathrm{m}}-\mathrm{maximal}$ fluorescent yield of the dark-adapted state; $\mathrm{F}_{\mathrm{v}}$ - variable fluorescence; $\mathrm{F}_{\mathrm{v}} / \mathrm{F}_{\mathrm{m}}$ - maximum quantum efficiency of PSII; $g_{\mathrm{s}}-$ stomatal conductance; $J_{\max }$ - rate of electron transport; $\mathrm{N}$ - nitrogen; NNF - Nebraska National Forest; NPP - net primary production; $P_{\mathrm{N}}-$ net photosynthetic rate; PNUE - photosynthetic nitrogen-use efficiency; $\mathrm{T}_{\mathrm{A}}$ - temperature of the air; $\mathrm{T}_{\mathrm{L}}$ - temperature of the leaf; $V_{\mathrm{cmax}}-$ maximum carboxylation velocity; VSWC - volumetric soil water content; WUE - water-use efficiency; $\delta^{13} \mathrm{C}$ - carbon isotope ratio; $\delta^{15} \mathrm{~N}$ - nitrogen isotope ratio; $\Psi_{\text {pre }}$ - predawn water potential; $\Psi_{\text {mid }}$ - midday water potential; $\Psi_{\mathrm{w}}$ - water potential.

Acknowledgements: This study was supported by the McIntire Stennis Forest Research Funds-USDA, and the Agricultural Research Division at the University of Nebraska-Lincoln (UNL). N. Bryan would like to acknowledge a fellowship from the Center for Great Plains Studies and the Department of Agronomy and Horticulture (UNL). We appreciate the assistance of the High Plains Regional Climate Center at UNL for sharing their weather data, the Water Sciences Laboratory and Ecosystems Analysis Laboratory at UNL for conducting the laboratory analyses, and reviewers for their comments and suggestions on the manuscripts.

“C The Author(s)." This article is published with open access at link.springer.com 
shifts from grass-dominated communities to open and, in some instances, closed-canopy woodlands. This trend has accelerated in recent decades (Wilcox 2010, Twidwell et al. 2013) modifying and in some cases threatening key ecosystem services (Norris et al. 2001, Throop et al. 2012, Nippert et al. 2013), including biodiversity (Pierce and Reich 2010), species distribution and composition (Dobson et al. 1997, Chapin et al. 1998, Norris et al. 2007), ecosystem NPP (Wilcox 2010), herbaceous (Ganguli et al. 2008) and livestock production (Throop et al. 2012), nutrient cycling (Archer 2010, Pierce and Reich 2010), and system ecohydrology (Eggemeyer et al. 2009, Awada et al. 2013). There is much to be learned about the implications of shifts from open grasslands and savannas to closed-canopy woodlands on water and biogeochemical cycles (Wilcox 2010, Nippert et al. 2013, Starks et al. 2014), and the feedback of these cycle and resource availability changes on plant ecophysiological performance. Furthermore, investigating the seasonal and spatial physiological activity are necessary for modeling efforts including the estimation and forecasting of energy, water and carbon exchange, as well as NPP of a plant community and its projected dynamics in the face of climate variability and change (Hamada et al. 2016).

Conversion of $\mathrm{C}_{4}$-dominated grasslands with relatively high photosynthetic capacity, high nitrogen- and water-use efficiencies and short growing season to $\mathrm{C}_{3}$ woodlands with lower photosynthetic rates, longer growing season, and lower nitrogen- and water-use efficiencies in low to mid-latitudinal regions of the Great Plains of the continental U.S. (Eggemeyer et al. 2006, Eggemeyer et al. 2009, Awada et al. 2013) has implications on NPP, biogeochemical and ecohydrological cycles (McKinley and Blair 2008, Wilcox 2010), and fire regime (D'Antonio and Vitousek 1992, Brooks et al. 2004). With respect to ecohydrology, woody species encroachment has been found to modify water distribution in soils through shifts in transpiration rates, more precipitation interception, and less water infiltration, potentially resulting in drier soils (Liao et al. 2008, Rout and Callaway 2009, Boutton and Liao 2010, Awada et al. 2013). These changes have negative impacts on grasses and resilience of the these ecosystems (Diez et al. 2012). Woody plant expansion or encroachment in semiarid grasslands also has been found to increase below- (Jackson et al. 2002) and aboveground C pools (Pacala et al. 2001, McCulley and Jackson 2012). McKinley and Blair (2008) reported an increase in total ecosystem $\mathrm{N}$ and $\mathrm{C}$ pools in Juniperus virginiana forests compared to grasslands, likely because the absence of fire in J. virginiana stands allowed substantial accrual of $\mathrm{C}$ and $\mathrm{N}$ in aboveground biomass and litter layers. In another study, Billings (2006) found that plant litterfall from forested sites (Ulmus sp. and Quercus sp.) had greater N concentration than that in smooth brome (Bromus inermis Leyss) grass sites.

In the Great Plains, substantial shifts in vegetation cover have been attributed to woody species expansion, including mesquite (Prosopis glandulosa Torr.) in Texas (Archer 1995), ponderosa pine (Pinus ponderosa P.\&C. Lawson) in the Black Hills of South Dakota (Shinneman and Baker 1997), and eastern red cedar (Juniperus virginiana, L.), which can be found in every state east of the $100^{\text {th }}$ meridian (McKinley and Blair 2008, Starks et al. 2014), encroaching into 7 million ha of grasslands, shrublands, and riparian forests in the Great Plains, along a precipitation gradient ranging from semiarid in its western distribution (Eggemeyer et al. 2009) to mesic in its eastern distribution (Willson et al. 2008).

Similar to other areas of the Great Plains, the semiarid grasslands of the Nebraska Sandhills - which at $50,000 \mathrm{~km}^{2}$ are the largest stabilized sand dune formation in the Western Hemisphere - are experiencing a nonlinear increase in the encroachment of $J$. virginiana [current rate exceeding 10,000 ha per year (Helmink 2012)]. Limited studies have addressed the ecophysiology of $J$. virginiana in the Nebraska Sandhills (e.g., Eggemeyer et al. 2006, Eggemeyer et al. 2009, Awada et al. 2013), and these studies did not investigate the impact of density or changes in plant-soil processes and resource availability associated with encroachment. The Sandhills offer a unique ecosystem due to their economic (i.e., livestock production) and ecological importance, and the potential implications of this encroachment on regional ecohydrology. The Nebraska Sandhills are a major recharge zone for the High Plains Ogallala Aquifer [36 and 65\% of the aquifer area and water, respectively, are located under Nebraska (Bleed and Flowerday 1998)]. Thus, woody species encroachment has the potential to significantly alter groundwater recharge (Awada et al. 2013), which is estimated to be 6 to $14 \%$ of annual precipitation in the Sandhills (Szilagyi et al. 2005), as well as soil $\mathrm{C}$ and $\mathrm{N}$ pools and carbon storage (Mellor et al. 2013). Additionally, the Sandhills occupy the drier region of the northern Great Plains where several years of consecutive drought are not uncommon (Awada et al. 2013).

The focus of this study was therefore to investigate shifts in key plant-soil processes associated with expansion of $J$. virginiana into grasslands, and their feedback on the ecophysiology of this species when found in open grasslands or mature dense-canopy woodland, in the drought prone semiarid grasslands of the Nebraska Sandhills, where the species is found in its most western locations. This was accomplished by investigating J. virginiana seasonal variability in water relations, photosynthetic capacity [including seasonal maximum carboxylation velocity $\left(V_{\text {cmax }}\right)$ and rate of electron transport $\left(J_{\max }\right)$, which to our knowledge have not been reported in the field for this species], and water- and nitrogen-use efficiencies as impacted by environmental variability and soil characteristics. Outcome from this study is also critical to developing ecophysiological predictive models for water, carbon and energy balance, and to forecasting the dynamics and performance of this species in grasslands of the Great Plains. 


\section{Materials and methods}

Sites characteristics: The study was conducted at the Nebraska National Forest (NNF), Halsey, Nebraska, USA (825 m a. s. 1., 41 $\left.{ }^{\circ} 51^{\prime} 45^{\prime \prime} \mathrm{N}, 100^{\circ} 22^{\prime} 06^{\prime \prime W}\right)$, between 2006 [starting day of year (DOY) 262] and 2007 over a 12 -month period. The NNF is managed by the US Forest Service, University of Nebraska, Lincoln. Most of the NNF is Sandhills grassland with about 10,000 ha handplanted coniferous species, including the invasive native $J$. virginiana. Climate is semiarid continental, with a mean annual precipitation of $570 \mathrm{~mm}, 75 \%$ of which falls during the growing season (April-September). Mean annual temperature is $8.4^{\circ} \mathrm{C}$. The mean minimum temperature in January is $-14^{\circ} \mathrm{C}$, and the mean maximum temperature in July is $31^{\circ} \mathrm{C}$. Soils are Valentine fine sand (mixed, mesic Typic Ustipsamments) with deep loose sandy well-drained soils.
Two sites were selected, a dense mature stand of $J$. virginiana (hereafter, dense), and an open grassland with young scattered individuals of $J$. virginiana (hereafter, open). Sites and trees characteristics are presented in the text table below. The dense $J$. virginiana site has little to no growth of understory species with the exception of occasional cacti (Opuntia spp.), and scattered individuals of sedges (Carex spp.). The open grassland site is composed of a low density overstory of $J$. virginiana and ponderosa pine (Pinus ponderosa Douglas ex C. Lawson), and a perennial grassland understory community of mostly $\mathrm{C}_{4}$ species, including prairie sandreed (Calamovilfa longifolia (Hook.) Scribn.), little bluestem (Schizachyrium scoparium), and switchgrass (Panicum virgatum). Kentucky bluegrass (Poa pratensis L.), yucca (Yucca spp L.), and pricklypear (Opuntia spp P. Mill) can also be found on site.

\begin{tabular}{lll}
\hline Parameter & Open & Dense \\
\hline Site tree density $\left[\mathrm{ha}^{-1}\right]$ & 43 & 537 \\
Site basal area $\left[\mathrm{m}^{2} \mathrm{ha}^{-1}\right]$ & 5.6 & 7.89 \\
Site average DBH [m] & $0.39 \pm 0.64$ & $0.10 \pm 0.26$ \\
Age [yr] (*Planted even-aged 57-year-old stand.) & $20-30$ & $57 *$ \\
Average DBH of trees in this study [m] & $0.39 \pm 0.64$ & $0.19 \pm 0.83$ \\
Average height of trees in this study [m] & $6.4 \pm 0.55$ & $9.1 \pm 0.38$ \\
Ratio of green canopy/total height of trees in this study [\%] & $0.99 \pm 0.004$ & $0.7 \pm 0.005$ \\
Average crown volume of trees in this study [m $\left.{ }^{3}\right]$ & $95.23 \pm 24.8$ & $21.45 \pm 2.4$ \\
\hline
\end{tabular}

Micrometeorological and soil measurements: Micrometeorological variables including precipitation, atmospheric relative humidity, and air and soil temperatures were continuously recorded with a weather station installed at each site during the study period. One set of soil moisture sensors (ML2 Theta Probe, Dynamax Inc., TX, US) were installed at soil depths of $0.2,0.4$, and $1 \mathrm{~m}$. Soil moisture sensors were installed in between the trees in the dense site, and in the open but close to the canopy in the open site. Measurements were taken every $15 \mathrm{~s}$ and stored as half-hourly means on a datalogger (CR10X, Campbell Scientific Inc., UT, US). In the dense stand, soil moisture data interruption occurred during the spring due to power problems, and data between DOY 225 and 350 were questionable for the sensor placed at $0.2 \mathrm{~m}$ depth, possibly due to rodent damage; thus data from these two periods were not incorporated in this study. Additionally, three replicates of volumetric soil water content (VSWC) [\%] in the upper $0.3 \mathrm{~m}$ and $2 \mathrm{~m}$ of the soil profile were collected regularly using the TRIME FM (IMCO, Germany) system with access tubes. Weather data from the station on site were validated against a station at Halsey, NE (High Plains Regional Climate Center, HPRCC, University of Nebraska, UNL; http://www.hprcc.unl.edu).

A total of 20 soil samples for each site, divided into litter and mineral soil $(0-0.15 \mathrm{~m})$, were collected within a
$20 \times 20$ m plot. Ammonium $\left(\mathrm{NH}_{4}^{+}\right)\left[\mathrm{mg}(\mathrm{N}) \mathrm{kg}^{-1}\right]$, nitrate $\left(\mathrm{NO}_{3}{ }^{-}\right)\left[\mathrm{mg}(\mathrm{N}) \mathrm{kg}^{-1}\right]$, elemental carbon (C) [\%] and nitrogen $(\mathrm{N})[\%]$, total soluble nitrogen (includes $\mathrm{NH}_{4}^{+}$, $\mathrm{NO}_{3}^{-}$, and soluble organic $\mathrm{N}$ ), and isotopic ratios of carbon $\left(\delta^{13} \mathrm{C}\right)[\% \mathrm{o}]$ and nitrogen $\left(\delta^{15} \mathrm{~N}\right)[\% \mathrm{o}]$ were determined. For $\mathrm{NH}_{4}{ }^{+}$and $\mathrm{NO}_{3}{ }^{-}$determination, soil samples were extracted using a $1 \mathrm{M}$ potassium chloride solution, shaken for $0.5 \mathrm{~h}$, and then allowed to settle overnight at $4{ }^{\circ} \mathrm{C}$. The settled solution was then pipetted out and sent to the Ecosystems Analysis Laboratory at the University of Nebraska for $\mathrm{NH}_{4}{ }^{+}$and $\mathrm{NO}_{3}{ }^{-}$analysis using a Lachat 8500 Series 2 Autoanalyzer (Lachat Instruments, Loveland CO, USA). The ${ }^{15} \mathrm{~N}$ and ${ }^{13} \mathrm{C}$ were determined separately on individual samples by combustion, and isotope ratio mass spectrometry using a Eurovector E3000 elemental analyzer interfaced with an Isoprime continuous flow isotope ratio mass spectrometer ( $G V$ Instruments, Manchester, UK). The ${ }^{15} \mathrm{~N}$ and ${ }^{13} \mathrm{C}$ were expressed relative to atmospheric nitrogen and PDB, respectively. Elemental composition of percent $\mathrm{C}$ and $\mathrm{N}$ was calculated using glutamic acid and ammonium sulfate, respectively. Sucrose, caffeine, and urea were analyzed to check for $\mathrm{C}$, and methionine was used for N. Analyses were conducted at the Water Sciences Laboratory, Nebraska Water Center, University of Nebraska, Lincoln (http://watercenter.unl.edu/waterscilab/Isotope.asp). 
Foliage ecophysiological measurements: Seasonal gasexchange measurements started in the late summer of 2006 (DOY 262) and were concluded 12 months later in 2007. Several unshaded, south-facing needle-like scale foliage were selected for the measurement. The number of individual samples $(n)$ per tree varied between 1 in winter and 4 during the growing season, and values from each tree per sampling date were pooled together for analysis to avoid pseudoreplication. Ladders were used to access the upper canopy. Net photosynthesis $\left(P_{\mathrm{N}}\right)$ [ $\mu \mathrm{mol} \mathrm{m} \mathrm{m}^{-2} \mathrm{~s}^{-1}$, stomatal conductance $\left(g_{\mathrm{s}}\right)\left[\mathrm{mol} \mathrm{m}^{-2} \mathrm{~s}^{-1}\right]$, and transpiration rates $(E)\left[\mathrm{mmol} \mathrm{m}^{-2} \mathrm{~s}^{-1}\right]$ were determined with an infra-red gas analyzer, with a $6 \mathrm{~cm}^{2}$ chamber mounted with a LED light source (LICOR 6400 - 02B; LICOR Inc., Lincoln NE, US). Measurements were conducted at light saturation PAR was set at 1,500 $\mu$ mol(photon) $\mathrm{m}^{-2} \mathrm{~s}^{-1}$ (Eggemeyer et al. 2006, Bihmidine et al. 2010) - and were conducted between 10:00 and 14:00 h solar time in winter, and 09:00 and 14:00 h solar time during the growing season. After completion of each measurement, and due to the scale-like foliage of $J$. virginiana, foliage material in the chamber was collected and measured with a leaf area meter (LICOR 3000; LICOR Inc., Lincoln NE, US) to correct for gasexchange measurements. The response of photosynthesis to intercellular $\mathrm{CO}_{2}$ concentration $\left(P_{\mathrm{N}} / C_{\mathrm{i}}\right.$ curve) was determined at light saturation following the protocol described in Long and Bernacchi (2003), Bihmidine et al. (2010), and Bihmidine et al. (2014). Maximum carboxylation velocity $\left(V_{\mathrm{cmax}}\right)\left[\mu \mathrm{mol} \mathrm{m} \mathrm{m}^{-2}\right]$ and rate of electron

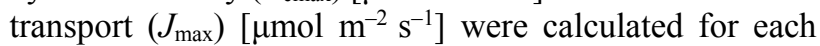
$P_{\mathrm{N}} / C_{\mathrm{i}}$ curve by nonlinear regression using the curve fitting utility (Sharkey et al. 2007). It was difficult to obtain reliable $P_{\mathrm{N}} / C_{\mathrm{i}}$ curves under certain environmental conditions (e.g., low soil water and/or low/high air temperatures), curves were not included in the analysis if data points were outside the physiologically possible limits, or points did not transition between Rubisco-carboxylation

\section{Results}

Micrometeorological and soil parameters: Average annual air temperature $\left(\mathrm{T}_{\mathrm{A}}\right)$ was slightly higher in open grassland with scattered young trees $\left(10.62^{\circ} \mathrm{C}\right)$ than in the dense mature stand of $J$. virginiana $\left(9.6^{\circ} \mathrm{C}\right)$. Trends corresponded well with historical records, reaching maximum in months of July and August $\left(\sim 30^{\circ} \mathrm{C}\right.$, DOY 181-244), and a minimum in January and February $\left(\sim-20^{\circ} \mathrm{C}\right.$, DOY 1-60; Fig. $\left.1 A\right)$. Cumulative precipitation was $590 \mathrm{~mm}$, slightly above the long-term average of $570 \mathrm{~mm}$, with the lowest precipitation recorded in July and August (cumulative $81 \mathrm{~mm}$ ) and in November and December (cumulative $34 \mathrm{~mm}$, DOY 306-365, Fig. 1A), and the highest in May and June (cumulative $208 \mathrm{~mm}$, DOY 122-182). Average volumetric soil water content (VSWC) was consistently and significantly greater in open grasslands with scattered $J$. virginiana, relative to the limited and RuBP-regeneration limited assimilation rate. Thus, figures for $V_{\text {cmax }}$ and $J_{\max }$ have missing data points and/or lack of standard error bars.

Chlorophyll (Chl) fluorescence of dark-adapted foliage was measured with a leaf chamber $\left(2 \mathrm{~cm}^{2}\right)$ fluorometer attached to the $L I-6400$ infrared gas analyzer (LICOR Inc., Lincoln NE, US). The variable fluorescence $\left(F_{v}\right)$ is the difference between $\mathrm{F}_{0}$ and $\mathrm{F}_{\mathrm{m}}$. When measured on darkadapted needles, $F_{\mathrm{v}} / F_{\mathrm{m}}$ is proportional to the maximum potential quantum yield of photosynthesis (Bihmidine et al. 2010). Predawn ( $\left.\psi_{\text {pre }}\right)[\mathrm{MPa}]$ and midday $\left(\psi_{\mathrm{mid}}\right)[\mathrm{MPa}]$ water potentials were measured using a pressure chamber (PMS Instrument Co., Albany OR, US). Nitrogen concentration $(\mathrm{N})[\%]$, and isotopic ratios of carbon $\left(\delta^{13} \mathrm{C}\right)[\% \mathrm{o}]$ and nitrogen $\left(\delta^{15} \mathrm{~N}\right)[\%$ ] were determined on several needles from each individual tree, including those used for gas-exchange measurements (Water Sciences Laboratory, Nebraska Water Center, University of Nebraska, Lincoln, http://watercenter.unl.edu/waterscilab/Isotope.asp).

Statistical analyses: Data were analyzed using $S A S$ statistical package (SAS Institute, Inc. 1998). Repeated measure analyses using the MIXED MODEL procedure in $S A S$ was used with trees as random factor and treatments (open $v s$. closed) as fixed factor, as well as regressions and orthogonal contrasts to compare species responses and to determine the effects of environmental conditions on measured parameters within and between species. Means were separated $(p<0.05)$ using the pairwise mean comparisons in $S A S$. Principle component analysis (PCA) was used to analyze both ecophysiological and morphological attributes associated with trees as impacted by density and resource availability. PCA was conducted using the $R$ open source programming ade4 multivariate data analysis package developed by Dray et al. (2007). The factoextra package supplemented the ade 4 package for the purposes of visualization of the multivariate outputs (Kassambara 2015).

dense stand (Fig. $1 B-F$ ), but differences became smaller with soil depth. On an annual basis, the VSWC in the top $2 \mathrm{~m}$ averaged $38 \%$ less in the dense stand of $J$. virginiana $(6.7 \%)$ compared to open grassland $(10.9 \%)$; these trends are consistent with Awada et al. (2013).

Ammonium $\left(\mathrm{NH}_{4}{ }^{+}\right)$, nitrate $\left(\mathrm{NO}_{3}{ }^{-}\right)$, and total inorganic $\mathrm{N}$ in the litter layer and mineral soil $(0-0.15 \mathrm{~m})$ were significantly greater by at least $25 \%$ in the open grassland with scattered young trees of $J$. virginiana than in the dense mature stand (Table 1). Available $\mathrm{N}$ declined by 20 and $27 \%$ in dense stand relative to open grassland, but total carbon and nitrogen increased by 18 and 37\%, respectively. As expected, the mineral soil carbon isotopic ratio $\left(\delta^{13} \mathrm{C}\right)$ was significantly higher (i.e., more enriched, $-23 \%$ ) in the open grassland with young $J$. virginiana trees than in the dense mature stand $(-25.9 \%)$ reflecting a 


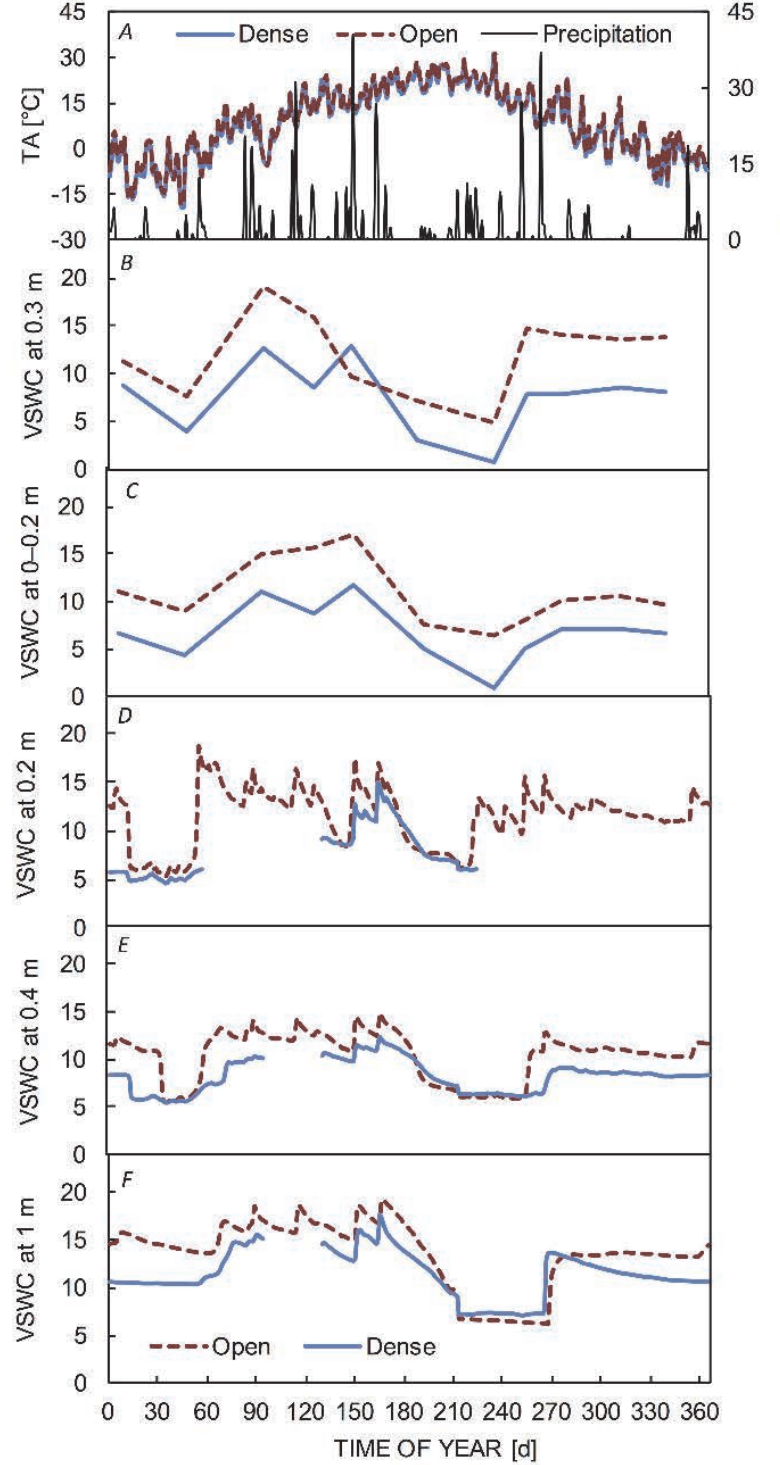

Fig. 1. Seasonal trends in average daily air temperature and precipitation $(A)$, volumetric soil water content at $0-0.3$ and $0-2 \mathrm{~m}$ using access tubes $(B, C)$, VSWC at $0.2,0.4,1 \mathrm{~m}$ using continuous measurements $(D, E, F)$ in open grasslands and dense stand of Juniperus virginiana in the semiarid grasslands of the Nebraska Sandhills between 2006-2007 (starting day of year 262 in 2006 and continuing for 12 months). Missing data points of VSWC in the dense stand were due to power problems in the spring, and sensor damage at the depth of $0.2 \mathrm{~m}$ between DOY 225 and 350 possibly due to rodent activity.

shift from $\mathrm{C}_{4}$-dominated to a $\mathrm{C}_{3}$-dominated community (Table 1). Isotopic $\mathrm{N}$ ratio $\left(\delta^{15} \mathrm{~N}\right)$ in the mineral soil was slightly more enriched in the dense mature $J$. virginiana stand $(0.45 \%)$ than in the open grassland with scattered young trees $(0.35 \%)$.

Ecophysiological parameters: Predawn $\left(\Psi_{\text {pre }}\right)$ and midday $\left(\Psi_{\text {mid }}\right)$ water potentials displayed significant seasonal variation that generally corresponded with VSWC in both
Table 1. Means and associated standard errors of measured soil and Juniperus virginiana foliage parameters in open grasslands with scattered $J$. virginiana and dense tree stand in the Nebraska Sandhills. ${ }^{*}$ - statistical significance between means at $p<0.05$.

\begin{tabular}{|c|c|c|}
\hline Parameter & Open & Dense \\
\hline \multicolumn{3}{|l|}{ Soil } \\
\hline $\begin{array}{l}\mathrm{NH}_{4}^{+}\left[\mathrm{mg} \mathrm{N} \mathrm{kg}^{-1}\right] \\
\text { Litter } \\
\text { Mineral Soil }\end{array}$ & $\begin{array}{l}12.66 \pm 2.3 \\
0.64 \pm 0.13\end{array}$ & $\begin{array}{l}6.5 \pm 0.58^{*} \\
0.48 \pm 0.04^{*}\end{array}$ \\
\hline $\begin{array}{l}\mathrm{NO}_{3}{ }^{-}\left[\mathrm{mg} \mathrm{N} \mathrm{kg}^{-1}\right] \\
\text { Litter } \\
\text { Mineral Soil }\end{array}$ & $\begin{array}{l}2.72 \pm 0.6 \\
0.30 \pm 0.04\end{array}$ & $\begin{array}{l}1.5 \pm 0.8^{*} \\
0.21 \pm 0.03^{*}\end{array}$ \\
\hline $\begin{array}{l}\text { Total Inorganic N [mg N } \\
\text { Litter } \\
\text { Mineral Soil }\end{array}$ & $\begin{array}{l}15.38 \pm 2.7 \\
0.94 \pm 0.16\end{array}$ & $\begin{array}{l}8.08 \pm 2.8^{*} \\
0.69 \pm 0.04^{*}\end{array}$ \\
\hline $\begin{array}{l}\text { Total Soluble N [mg N k } \\
\text { Litter } \\
\text { Mineral Soil }\end{array}$ & $\begin{array}{l}17.25 \pm 2.5 \\
33.6 \pm 3.02\end{array}$ & $\begin{array}{l}13.3 \pm 9.8 \\
24.5 \pm 1.8^{*}\end{array}$ \\
\hline $\begin{array}{l}\text { Carbon [\%] } \\
\text { Nitrogen [\%] } \\
\delta^{13} \mathrm{C} \text { Mineral Soil }[\% 0] \\
\delta^{15} \mathrm{~N} \text { Mineral Soil }[\% 0]\end{array}$ & $\begin{array}{l}1.18 \pm 0.23 \\
0.53 \pm 0.07 \\
-23.0 \pm 0.30 \\
0.35 \pm 1.05\end{array}$ & $\begin{array}{l}1.40 \pm 3.10 \\
0.73 \pm 0.11^{*} \\
-25.9 \pm 0.80^{*} \\
0.45 \pm 0.81\end{array}$ \\
\hline \multicolumn{3}{|l|}{ Foliage } \\
\hline $\begin{array}{l}P_{\mathrm{N}}\left[\mu \mathrm{mol}\left(\mathrm{CO}_{2}\right) \mathrm{m}^{-2} \mathrm{~s}^{-1}\right] \\
g_{\mathrm{s}}\left(\mathrm{mol}\left(\mathrm{H}_{2} \mathrm{O}\right) \mathrm{m}^{-2} \mathrm{~s}^{-1}\right] \\
E\left[\mathrm{mmol}\left(\mathrm{H}_{2} \mathrm{O}\right) \mathrm{m}^{-2} \mathrm{~s}^{-1}\right] \\
\text { WUE }\left[P_{\mathrm{N}} / g_{\mathrm{s}}\right] \\
\text { PNUE }\left[P_{\mathrm{N}} / \mathrm{N}\right] \\
\Psi_{\text {pre }}[\mathrm{MPa}] \\
\Psi_{\operatorname{mid}}[\mathrm{MPa}] \\
\mathrm{F}_{\mathrm{v}} / \mathrm{F}_{\mathrm{m}} \\
V_{\mathrm{cmax}}\left[\mu \mathrm{mol} \mathrm{m}^{-2} \mathrm{~s}^{-1}\right] \\
J_{\max }\left[\mu \mathrm{mol} \mathrm{m}^{-2} \mathrm{~s}^{-1}\right] \\
\mathrm{C}[\%] \\
\mathrm{N}[\%] \\
\delta^{13} \mathrm{C}[\% 0] \\
\delta^{15} \mathrm{~N}[\%]\end{array}$ & $\begin{array}{l}8.55 \pm 1.3 \\
0.11 \pm 0.018 \\
2.26 \pm 0.47 \\
76.8 \pm 5.7 \\
5.37 \pm 0.77 \\
-0.49 \pm 0.05 \\
-1.48 \pm 0.13 \\
0.72 \pm 0.045 \\
33.67 \pm 1.52 \\
137.04 \pm 3.25 \\
47.3 \pm 1.16 \\
1.56 \pm 0.036 \\
-24.8 \pm 0.16 \\
-2.48 \pm 0.086\end{array}$ & $\begin{array}{l}8.3 \pm 1.33 \\
0.11 \pm 0.02 \\
2.17 \pm 0.48 \\
73.4 \pm 6.88 \\
8.78 \pm 1.22^{*} \\
-0.72 \pm 0.07^{*} \\
-1.59 \pm 0.14 \\
0.78 \pm 0.045 \\
31.50 \pm 1.94 \\
130.3 \pm 7.02 \\
48.3 \pm 0.71 \\
0.99 \pm 0.037^{*} \\
-26.6 \pm 0.063^{*} \\
-5.9 \pm 0.095^{*}\end{array}$ \\
\hline
\end{tabular}

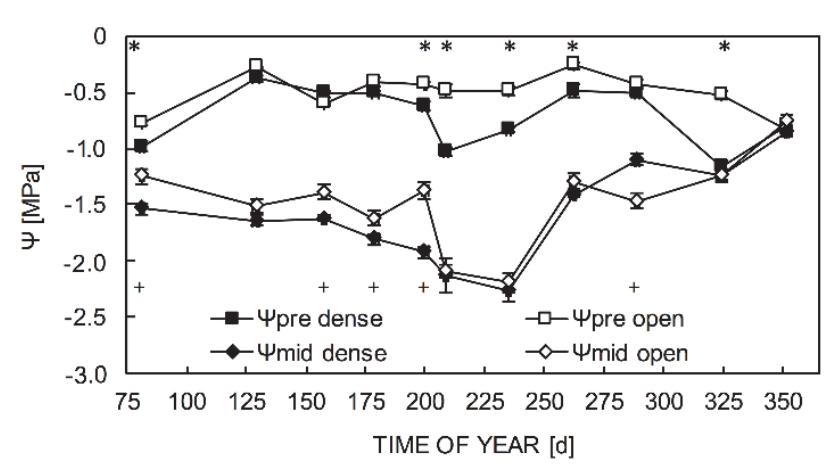

Fig. 2. Seasonal trends in average predawn $\left(\Psi_{\text {pre }}\right)$ and midday $\left(\Psi_{\text {mid }}\right)$ water potential with standard error bars, in open grasslands (open symbols) and dense stand (full symbols) of Juniperus virginiana in the semiarid grasslands of the Nebraska Sandhills between 2006-2007 (starting day of year 262 in 2006 and continuing over 12 months). ${ }^{*}$ - significant differences between open and dense within a sampling date $(p<0.05, n=5$ trees). 


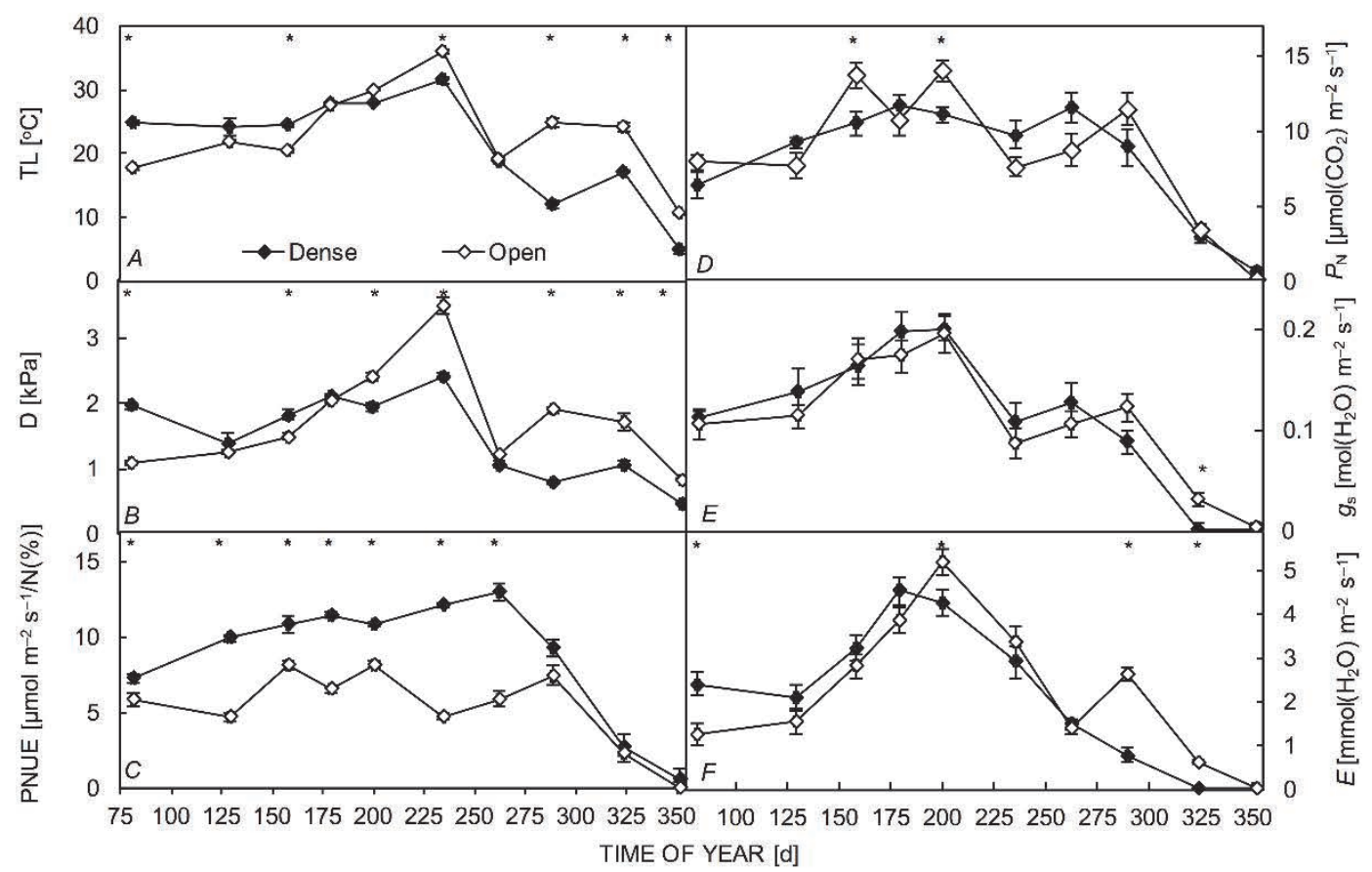

Fig. 3. Seasonal trends in average leaf temperature $(A)$, vapor pressure deficit $(B)$, photosynthetic nitrogen-use efficiency $(C)$, net photosynthesis at light saturation $(D)$, stomatal conductance $(E)$, and transpiration rates $(F)$, with standard error bars, in open grasslands (open symbols) and dense stand (full symbols) of Juniperus virginiana in the semiarid grasslands of the Nebraska Sandhills (between 2006-2007, starting day of year 262 in 2006 and continuing over 12 months). * - significant differences between open and dense within a sampling date $(p<0.05, n=5$ trees $)$.

open and dense J. virginiana sites (Fig. 2). Although significantly lower $\Psi_{\text {pre }}$ were not observed in the dense mature stand relative to open grassland with young scattered $J$. virginiana trees until mid-July to midSeptember (DOY 200-262), $\Psi_{\text {mid }}$ in the spring and summer (DOY 75-200) was significantly lower on the dense mature site than that of the open grassland. $\Psi_{\text {mid }}$ reached its lowest values at both sites toward the end of July (DOY 209), and remained low until the end of August (DOY 235) with an average $-2.2 \mathrm{MPa}$, before recovering with increased water availability.

Gas-exchange measurements indicated that $P_{\mathrm{N}}, g_{\mathrm{s}}$, and $E$ of young and mature trees of $J$. virginiana trees growing in open grassland and dense sites, respectively, followed expected seasonal trends, being low in the fall, winter and late summer, and increasing with the improvement in weather conditions in the spring reaching highest values during the summer (Fig. $3 D-F$ ). Maximal values of $P_{\mathrm{N}}$ were observed in young trees in open grassland and were attained in June (DOY 158) and July (DOY 200), averaging $14.03 \mu \mathrm{mol} \mathrm{m} \mathrm{m}^{-2} \mathrm{~s}^{-1}$. Trees in the dense mature site had lower $P_{\mathrm{N}}$, averaging $10.9 \mu \mathrm{mol} \mathrm{m} \mathrm{m}^{-2} \mathrm{~s}^{-1}$ during the same period. $P_{\mathrm{N}}$ did not differ during the remainder of the study period, and rates continued to vary a little throughout the growing season. The significant drop of $P_{\mathrm{N}}$ in the open grassland on DOY 235 was related to significantly higher leaf temperature $\left(\mathrm{T}_{\mathrm{L}}\right)$ and vapor pressure deficit $(\mathrm{D})$ on that sampling date relative to dense mature site. This impacted $g_{\mathrm{s}}$ and $E$, and potentially increased photorespiration leading to a reduction in $P_{\mathrm{N}}$. By DOY 200 (July), $g_{\mathrm{s}}$ and $E$ had peaked for both sites before declining for the remainder of the season. While $g_{\mathrm{s}}$ showed little variability between the two sites, $E$ was generally higher in $J$. virginiana in open grassland than that in dense canopy (Fig. 3E,F).

The maximum efficiency of PSII $\left(\mathrm{F}_{\mathrm{v}} / \mathrm{F}_{\mathrm{m}}\right)$ followed a similar trend in young and mature $J$. virginiana trees growing in open grassland and the dense sites, respectively, with efficiency peaking in early summer and declining gradually in the fall and into the winter (value of $\sim 0.4$ in December, DOY 352). Younger trees growing in the open grassland seemed to recover faster in March (DOY 82), exhibiting significantly higher values than their counterparts in the dense mature stand (Fig. 4A), associated possibly with faster snow melt and warming of soils in grasslands relative to the dense stand, as well as higher nitrogen content in needles. The maximum carboxylation velocity $\left(V_{\mathrm{cmax}}\right)$ and maximum rate of electron transport $\left(J_{\max }\right)$ did not did differ between $J$. virginiana trees from open and dense stands during the growing season (Fig. $4 B, C$ ); however, $V_{\mathrm{cmax}}$ and $J_{\max }$ in the mature dense stand declined faster in mid-October (DOY 290), and exhibited slower recovery in early spring (end of March, DOY 82) compared to younger trees in the open grassland. This was consistent with $\mathrm{F}_{\mathrm{v}} / \mathrm{F}_{\mathrm{m}}$ recovery and could be associated with more favorable climatic and light conditions during these periods and higher foliage $\mathrm{N}$ in open grassland vs. dense stand (Hamada et al. 2016). 


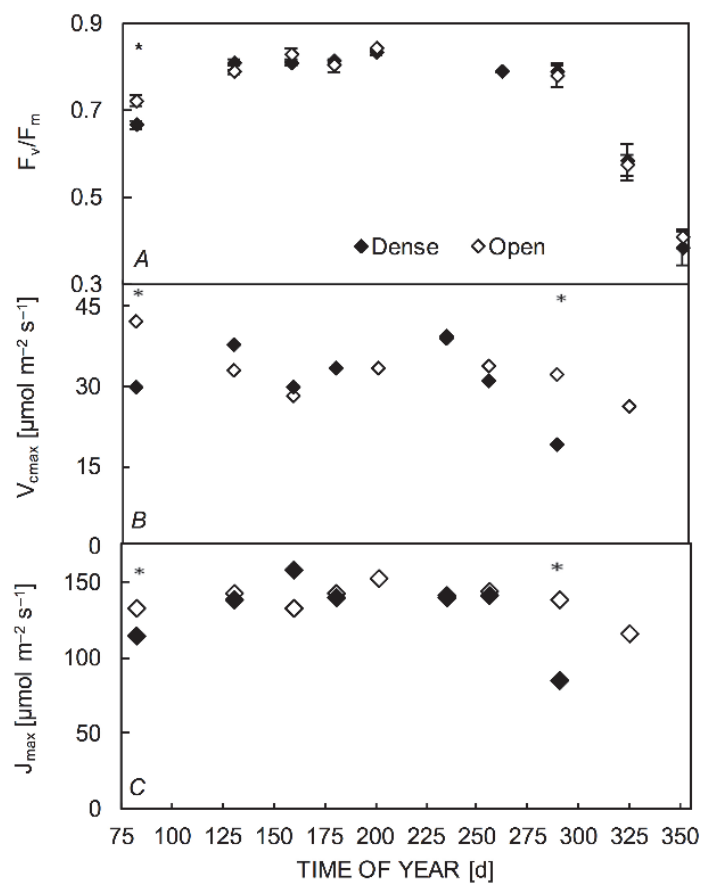

Fig. 4. Seasonal trends in average photosynthetic efficiency of photosystem II in dark-adapted leaves $(A)$, maximum carboxylation velocity $(B)$, and rate of electron transport $(C)$, in open grasslands (open symbols) and dense stand (full symbols) of Juniperus virginiana in the semiarid grasslands of the Nebraska Sandhills. It was difficult to obtain enough samples for reliable measurements of $V_{\text {cmax }}$ and $J_{\max }$ during periods of low or high temperatures and when water was limiting, thus the absence of data points and standard error bars on some dates. * - significant differences between open and dense within a sampling date $(p<0.05)$.

Photosynthetic N-use efficiency and needle $\mathrm{C}$ and $\mathrm{N}$ isotopic signatures: Carbon content of $J$. virginiana foliage did not differ between sites and showed very little seasonal variability, averaging around $50 \% \mathrm{C}$ (Fig. 1S, supplement available online). Foliage $\mathrm{N}$ concentration was higher in young trees in open grassland relative to mature trees in dense site (average $1.5 \%$ vs. $1 \%$ ), reflecting the decline in $\mathrm{N}$ availability in the later (Fig. 1S). Foliage $\mathrm{N}$ exhibited seasonal variability; however, this variability was not statistically significant because of the relatively large standard error that was observed on select sampling

\section{Discussion}

Woody plant encroachment in grassland and savanna ecosystems is a global phenomenon (Archer 1994, Binggeli 1996, Ganguli et al. 2008). In the Great Plains of the US, woody species expansion is one of the greatest contemporary threats (Briggs et al. 2005, Twidwell et al. 2013), converting millions of hectares of grasslands and shrub lands to woodlands and forests (McKinley and Blair 2008), and resulting in shifts in resource availability, dates (May-June, DOY 12-200 in open site, and November-December, DOY 234-352 in dense site; Fig. 1S). This resulted in higher $\mathrm{N}$-use efficiency (PNUE) in the dense mature stand for most of the growing season (Fig. 3C; March-September, DOY 81-262), with seasonal means of $10.77 v s$. 6.28 in the dense and open sites, respectively. PNUE decreased sharply in November and December (DOY 324-352), mainly associated with the seasonal decline in photosynthetic activity.

Needle $\delta^{15} \mathrm{~N}$ and $\delta^{13} \mathrm{C}$ isotopic ratios differed significantly between sites (Fig. 1S). $\delta^{15} \mathrm{~N}$ was more enriched in $J$. virginiana needles of young trees in open grassland and showed no seasonal variation (values ranged from -2 to $-3 \%$ ), compared to those from dense mature stand (values ranged from -5 to $-6.5 \%$; Fig. $1 \mathrm{~S})$. Foliage $\delta^{13} \mathrm{C}$ ratio was similarly less enriched in dense stands and showed little seasonal change (values ranged from -26 to $-27 \%$ ), compared to those sampled from open grassland $(-24$ to $-25.5 \%$ ), indicating a significantly greater intrinsic wateruse efficiency (WUE) of $J$. virginiana trees in open grassland compared to dense tree site (Fig. 1S, Fig. 5). $\delta^{13} \mathrm{C}$ ratio was positively related to $\mathrm{N}$ content and but insignificantly negatively related to PNUE (Fig. 5), however, when data were averaged across all sampling dates (Table 1), results showed the predicted significantly higher PNUE and lower $\delta^{13} \mathrm{C}$ ratio or WUE in dense stand compared to open grassland site.

Principle component analysis (PCA): The first two axis of the PCA explained a total of $70.8 \%$ of the variability between $J$. virginiana trees in open grasslands and dense forest (PC1 and PC2 explained 43.3 and $27.5 \%$ of the variance, respectively). $g_{\mathrm{s}}, \mathrm{F}_{\mathrm{v}} / \mathrm{F}_{\mathrm{m}}, P_{\mathrm{N}}, E, \Psi_{\text {pre }}$, and PNUE were strongly correlated to the first principal component (PC1) (Fig. 6). These attributes changed as expected in a directional way over seasons, and based on the strong correlations of $g_{\mathrm{s}}$ and $E$ with PC1 (0.88 and 0.82, respectively), we can conclude that these two variable are good predictors in $\mathrm{PC} 1$ over the seasons, in both open grassland and dense stand. PC2 was strongly correlated to $\mathrm{N}(0.93), \delta^{15} \mathrm{~N}(0.94)$, and $\delta^{13} \mathrm{C}(0.84)$, suggesting that these variables are key in separating the $J$. virginiana in open grasslands from mature individuals in dense forests, and reflect the changes in resource availability that grassland ecosystems undergo in response to vegetation shift.

ecosystem processes, productivity and the services they provide. Our results demonstrated significant shifts in ecosystem services within 60 years of land conversion, i.e., from a diverse $\mathrm{C}_{4}$-dominated grassland to an even-aged (57 yrs.) stand of $J$. virginiana with sparse understory. The shift to a dense stand of $J$. virginiana resulted in drier soils, in the top $0.3 \mathrm{~m}$ for most of the year, which may impact the ecohydrological cycle (Huxman et al. 2005, Bond 


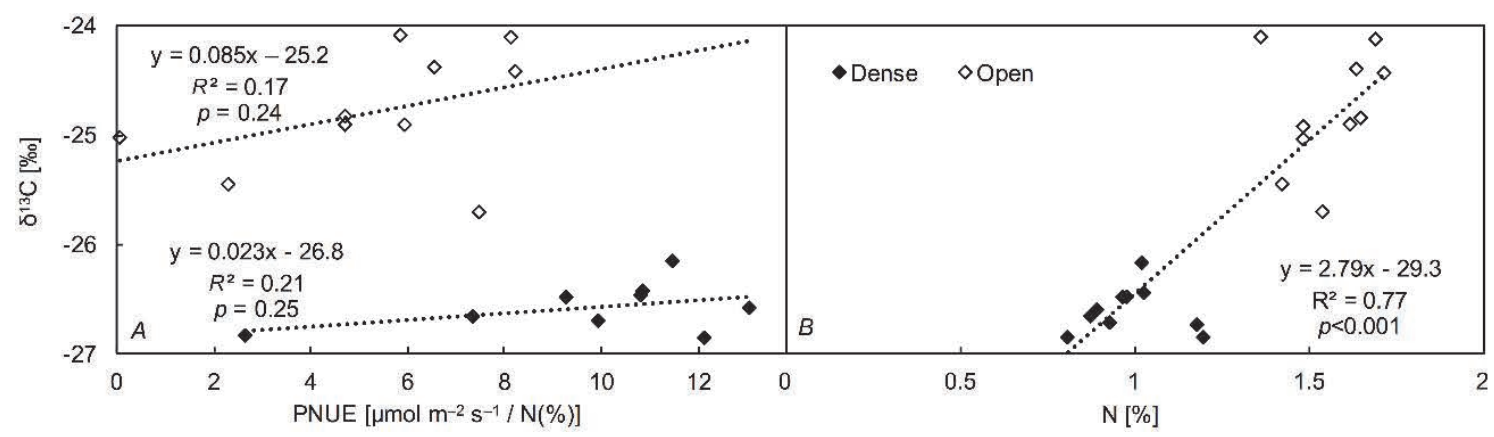

Fig. 5. Relationship between carbon isotopic ratio $\left(\delta^{13} \mathrm{C}\right)$ and photosynthetic nitrogen-use efficiency (PNUE) or foliage nitrogen content $(\mathrm{N})$, in open grasslands (open symbols) and dense stand (full symbols) of Juniperus virginiana in the semiarid grasslands of the Nebraska Sandhills.

2008, Volder et al. 2010, Awada et al. 2013, Zou et al. 2014). Our previous work on J. virginiana in the Sandhills of Nebraska has shown that $J$. virginiana trees compete for soil moisture with grasses in top layers when water is available during spring and early summer, and shift water uptake to deeper layers with decrease in surface moisture (Eggemeyer et al. 2009, Awada et al. 2013). In addition, the shift in allocation of biomass in trees associated $\mathrm{C}$ and $\mathrm{N}$ pools to above ground can alter the biogeochemical cycles and impact nutrient availability (Li et al. 2012). Litter decomposition of $J$. virginiana is much slower than that of grassland herbaceous plants because of its chemical composition (Mellor et al. 2013); and despite organic N accumulation in litter of $J$. virginiana needles, it appears to contribute little to the inorganic $\mathrm{N}$ in the mineral soils in the short term $[<2$ years, McKinley (2007)]. J. virginiana has also a longer growing season (most of the year) than grasses, and is capable of depleting soil nutrients and sequestering them in aboveground biomass which exacerbates the problem of nutrient limitations (McKinley et al. 2008). Mineral soil $(0-0.15 \mathrm{~m})$ analyses showed a slight but insignificant increase of $\delta^{15} \mathrm{~N}$ (more enriched) in dense site compared to open grassland (Table 1), while plant tissue (needles) $\delta^{15} \mathrm{~N}$ showed that tree foliage in open grassland was significantly more enriched in ${ }^{15} \mathrm{~N}$ than in dense $J$. virginiana stand (Fig. 1S). The $\delta^{15} \mathrm{~N}$ has been used to evaluate $\mathrm{N}$ cycling status and responses to environmental changes in an ecosystem by providing a measure that integrates present and past $\mathrm{N}$ cycling processes (Pardo et al. 2002). Microbes discriminate against the heavier ${ }^{15} \mathrm{~N}$, therefore microbial nitrification produces ${ }^{15} \mathrm{~N}$-depleted $\mathrm{NO}_{3}{ }^{-}$and ${ }^{15} \mathrm{~N}$-enriched $\mathrm{NH}_{4}{ }^{+}$. Nitrification increases when $\mathrm{N}$ availability exceeds uptake (van der Sleen et al. 2015), and if not taken up by plants, depleted $\mathrm{NO}_{3}{ }^{-}$is leached, contrary to the enriched $\mathrm{NH}_{4}{ }^{+}$, which is retained on the soil exchange surface. Thus, increased nitrification results in gradual ${ }^{15} \mathrm{~N}$ enrichment over time of the soil profile, plants, and of the available $\mathrm{NH}_{4}{ }^{+}$pool (Pardo et al. 2002). We did not measure soil layers below $0.15 \mathrm{~m}$, and plants do not fractionate upon $\mathrm{N}$ uptake (i.e., if soils are enriched so would be the plants), therefore, plants generally should have a $\delta^{15} \mathrm{~N}$ that is reflective of the inorganic $\mathrm{N}$ source. $J$. virginiana was found to have roots that extend below $7 \mathrm{~m}$ of the soil surface and is able to uptake water from deep in the soil profile (Eggemeyer et al. 2009). Mycorrhizal associations (Liang et al. 2008), like those found in J. virginiana (Williams et al. 2013), and the lower soil nutrients in the dense stand relative to the open, seems to have altered microbial $\mathrm{N}$ cycling, to become tighter in dense stands, leading to a greater depletion of foliar $\delta^{15} \mathrm{~N}$ (van der Sleen et al. 2015).

Ecophysiological responses to changes in the environment: Surface soils in the dense $J$. virginiana site were consistently drier than those of open grasslands for most of the year; differences declined with soil depth. Drier surface soils, and significantly lower $\Psi_{\text {pre }}$ and $\Psi_{\text {mid }}$ in trees in the dense site during the summer months relative to open site (Fig. 2) did not seem to have a negative feedback on the performance of $J$. virginiana trees growing in densecanopy site, which maintained physiological activity and generally exhibited similar trends for $P_{\mathrm{N}}, g_{\mathrm{s}}, E, V_{\mathrm{cmax}}, J_{\max }$, $\mathrm{F}_{\mathrm{v}} / \mathrm{F}_{\mathrm{m}}$ to trees growing in the grassland site during the growing season, however $V_{\mathrm{cmax}}, J_{\max }, \mathrm{F}_{\mathrm{v}} / \mathrm{F}_{\mathrm{m}}$ declined faster in the fall and recovered at a later date in the spring in dense compared to open grasslands trees (Figs. 3,4). The lower $V_{\text {cmax }}, J_{\max }, \mathrm{F}_{\mathrm{v}} / \mathrm{F}_{\mathrm{m}}$ in trees in dense $v s$. open canopy in the fall and spring could be related to lower Rubisco concentration (Wilson et al. 2000), redistribution of limited resources during the winter acclimation process which results in slight increase in $\mathrm{N}$ (also observed in this study, Muller et al. 2009) and/or photoinhibition which shade trees are more susceptible to (Miyazawa et al. 2007). Understanding the dynamics and peak of these parameters are critical for accurately modeling and forecasting energy budgets and NPP (Hamada et al. 2016). J. virginiana is considered a drought tolerant species (Bihmidine et al. 2010) and has the ability to maintain stomatal opening and photosynthetic activity at relatively low water potentials (Eggemeyer et al. 2006, Willson et al. 2008), reaching xylem cavitation and $50 \%$ loss of conductivity at 

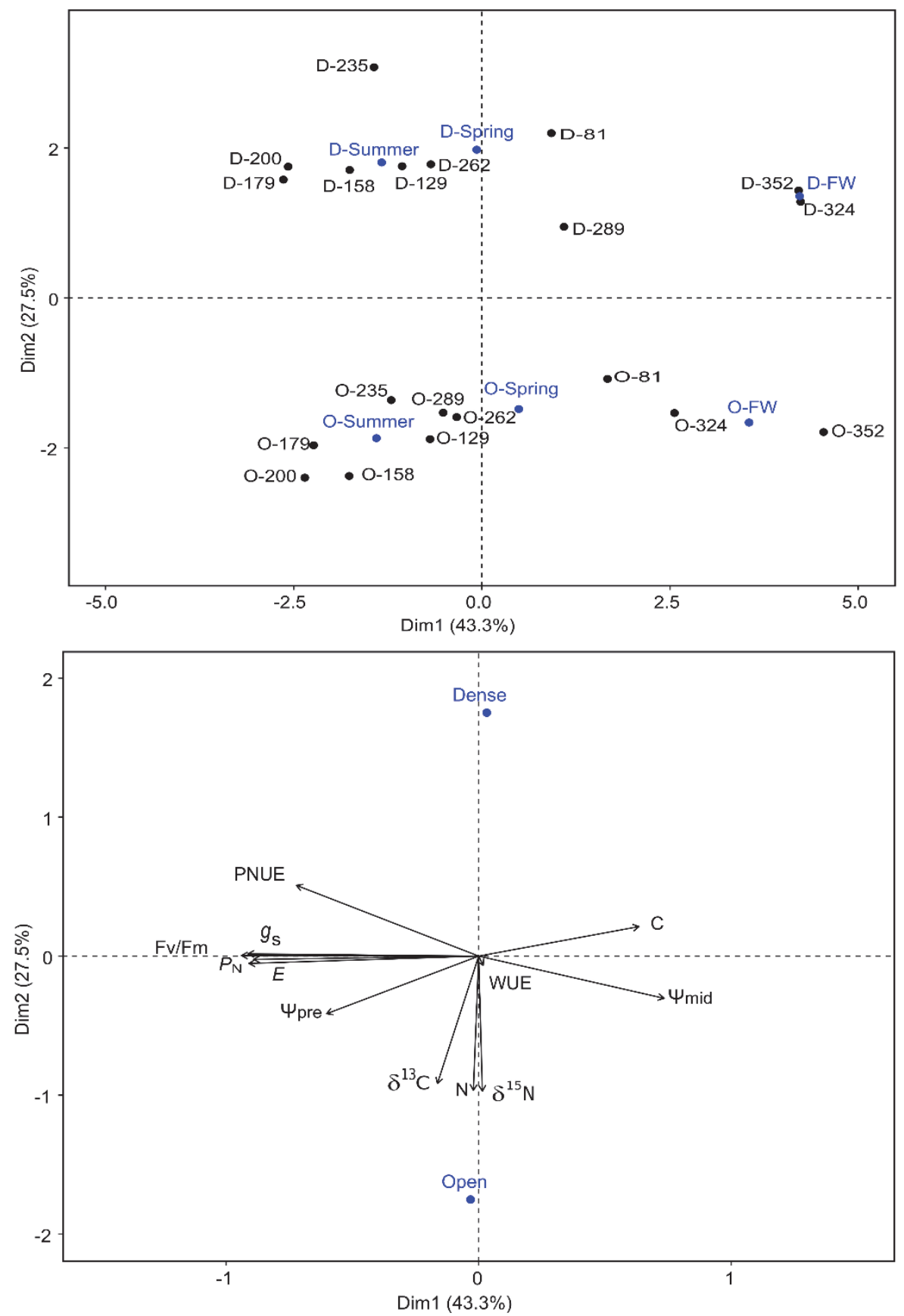

Fig. 6. Principal Component Analysis scores for PC1 (Dim1) and PC2 (Dim2) represent in a biplot for Juniperus virginiana in open grasslands $(\mathrm{O})$ and dense forest stand (D) $(A)$. The number following the letter represents the day of year measurements were collected. $\mathrm{O} / \mathrm{D}$-Spring, O/D-Summer, and O/D-FW represent the average scores of trees in the spring, summer, and fall-winter seasons in open grasslands $(\mathrm{O})$ or dense forest (D). Principal Component Analysis correlation circle of 12 variables measured on all sampled days $(B)$ : net photosynthesis $\left(P_{\mathrm{N}}\right)$, transpiration $(E)$, quantum efficiency of photosystem II $\left(\mathrm{F}_{\mathrm{v}} / \mathrm{F}_{\mathrm{m}}\right)$, stomatal conductance $\left(g_{\mathrm{s}}\right), \Psi_{\text {pre }}$ and $\Psi_{\text {mid }}$ water potentials, carbon and nitrogen isotopic ratio $\left(\delta^{13} \mathrm{C}\right.$ and $\left.\delta^{15} \mathrm{~N}\right)$, nitrogen content $(\mathrm{N})$, water-use efficiency (WUE), carbon (C), and photosynthetic nitrogen-use efficiency (PNUE). $V_{\mathrm{cmax}}$ and $J_{\max }$ have missing data points and thus were not incorporated in the analysis. O-Open and D-Dense represent average scores for both PC1 (Dim1) and PC2 (Dim2) across the entire study period for all parameters.

$\Psi_{\mathrm{w}}=-5.8[\mathrm{MPa}]$ in stems and $\Psi_{\mathrm{w}}=-4.9[\mathrm{MPa}]$ in roots (Willson et al. 2008), values that were not reached in this study. J. virginiana expands and survives in arid and semiarid environments because it has significant plasticity in water uptake (Eggemeyer et al. 2009, Caterina et al. 2014) and access to deeper soil layers (roots can reach $7 \mathrm{~m}$ 
deep) where water is available during the periods of low water availability (Walker and Noy-Meir 1982). That said, tree growth does not only depend on energy capture and photosynthetic rates, but also on the efficiency and effectiveness of carbohydrate integration, as well as the costs of maintaining and producing the photosynthetic system (Givnish 1988). J. virginiana in the dense stand maintained photosynthetic activity during the growing season and dealt with water stress by maintaining $\Psi_{\mathrm{w}}$ above a threshold (Willson et al. 2008), due in part to the significantly smaller trees and canopy size in dense $v s$. open grassland despite the age difference between trees in the two sites, resulting from competition for resources, as well as self-pruning under low light conditions - height and crown volume in dense canopy were 30 and $77 \%$, respectively, lower than in the open grassland. Awada et al. (2013) and Caterina et al. (2014) reported a positive functional relationship between sap wood area, tree diameter, canopy size, foliage and water use in J. virginiana. The higher water-use efficiency expressed by $\delta^{13} \mathrm{C}$ values in trees in the open grasslands relative to dense forest could be attributed to internal $\mathrm{CO}_{2}$ availability, irradiance intensity, and/or the source of $\mathrm{CO}_{2}$ isotopic composition in trees from dense vs. open canopy (Ehleringer et al. 1986).

Conclusion: Woody plant encroachment in grassland and savanna ecosystems continues to be a significant threat, resulting in major and persistent shifts in ecosystem structure, function, and composition, and the services provided (Archer 1994, Binggeli 1996, Ganguli et al. 2008, Liu et al. 2013, Archer and Predick 2014, Bestelmeyer et al. 2015). Our results made new contribution to the mounting literature on woody species expansion into grassland ecosystems, and showed the importance of understanding the dynamics of ecophysiologial traits and their responses to changes in the environment, to improve estimations of ecosystem services components including NNP, energy balance, and dynamic of vegetation in response to environmental variability.

We demonstrated in this study that $J$. virginiana in its most western location led to a shift in vegetation composition, water availability, and soil characteristics, with significant plasticity in response to resource availability (i.e., nutrients, light, and water) and limitation. This species with other drought tolerant species in the ecosystem may play a dual role in the face of climate change, by maintaining ecosystem functioning in the face of drought providing resilience, and/or encroached areas with low biological and functional diversity may negatively impact resilience. Better understanding of the mechanisms of vegetation shift, physiological resistance strategies of species in grasslands in response to abiotic and biotic environmental stresses associated with climate variability and change, and thresholds in the face of climate extremes, are important for predicting the directional changes of these ecosystems in the face of climate change (Craine et al. 2013). Additionally, they are also important for the development of adaptive management plans that can be implemented to either slow or control the encroachment and progression of $J$. virginiana and other woody species into grassland and savanna ecosystems, assist in the restoration of these ecosystems (depending on the state and degree of alteration), or concentrate on the new status quo (Bestelmeyer et al. 2015, Yahdjian et al. 2015). In the end, management decisions will depend on the ecological and economic service values that managers and society places on these new altered and persistent ecosystems (Bestelmeyer et al. 2015, Yahdjian et al. 2015).

Open Access This article is distributed under the terms of the Creative Commons Attribution License which permits any use, distribution, and reproduction in any medium, provided the original author(s) and the source are credited.

\section{References}

Archer S.R: Woody plant encroachment into southwestern grasslands and savannas: rates, patterns and proximate causes. - In: Vavra M., Laycock W.A., Pieper R.D. (ed.): Ecological Implications of Livestock Herbivory in the West. Pp. 13-68. Soc. Range Manage., Denver 1994.

Archer S.R.: Rangeland conservation and shrub encroachment: new perspectives on an old problem. - In: du Toit J.T., Kock R., Deutsch J.C. (ed.): Wild Rangelands: Conserving Wildlife While Maintaining Livestock in Semi-arid Ecosystems. Pp. 5397. John Wiley and Sons Ltd., Chichester 2010.

Archer S.R.: Tree-grass dynamics in a Prosopis-thornscrub savanna parkland: Reconstructing the past and predicting the future. - Ecoscience 2: 83-99, 1995.

Archer S.R., Predick K.I.: An ecosystem services perspective on brush management: research priorities for competing land use objectives. - J. Ecol. 102: 1394-1407, 2014.

Awada T., El-Hage R., Geha M. et al.: Intra-annual variability and environmental controls over transpiration in a 58-year-old even-aged stand of invasive woody Juniperus virginiana $\mathrm{L}$. in the Nebraska Sandhills, USA. - Ecohydrology 6: 731-740, 2013.

Bestelmeyer B.T., Okin G.S., Duniway M.C. et al.: Desertification, land use, and the transformation of global drylands. Front. Ecol. Environ. 13: 28-36, 2015.

Bihmidine S., Bryan N.M., Payne K.R. et al.: Photosynthetic performance of invasive Pinus ponderosa and Juniperus virginiana seedlings under gradual soil water depletion. - Plant Biol. 12: 668-675, 2010.

Bihmidine S., Cao M., Kang M. et al.: Expression of the Chlorovirus MT325 aquaglyceroporin (aqpv1) in tobacco and its role in mitigating drought stress. - Planta 240: 209-221, 2014

Billings S.A.: Soil organic matter dynamics and land use change at a grassland/forest ecotone. - Soil Biol. Biochem. 38: 2934 2943, 2006. 
Binggeli P.: A taxonomic, biogeographical and ecological overview of invasive woody plants. - J. Veg. Sci. 7: 121-124, 1996.

Bleed A.S., Flowerday C.A.: An Atlas of the Sandhills. Pp. 260. Conservation and Survey Division, University of Nebraska, Lincoln 1998.

Bond W.J.: What limits trees in $\mathrm{C} 4$ grasslands and savannas? Annu. Rev. Ecol. Syst. 39: 641-659, 2008.

Boutton T.W., Liao J.D.: Changes in soil nitrogen storage and $\delta^{15} \mathrm{~N}$ with woody plant encroachment in a subtropical savanna parkland landscape. - J. Geophys. Res 115: G03019, 2010.

Briggs J.M., Knapp A.K., Blair J.M. et al.: An ecosystem in transition: causes and consequences of the conversion of mesic grassland to shrubland. - BioScience 55: 243-254, 2005.

Brooks M.L., D'Antonio C.M., Richardson D.M. et al.: Effects of invasive alien plants on fire regimes. - BioScience 54: 677688, 2004.

Caterina G.L., Will R.E., Turton D.J. et al.: Water use of Juniperus virginiana trees encroached into mesic prairies in Oklahoma, USA. - Ecohydrology 7: 1124-1134, 2014.

Chapin F.S., Matson P.A., Vitousek P.: Principles of Terrestrial Ecosystem Ecology. Pp. 123-181. Springer-Verlag, New York 2011.

Chapin F.S., Sala O.E., Burke I.C. et al.: Ecosystem consequences of changing biodiversity. - BioScience 48: 45-52, 1998

Craine J.M., Ocheltree T.W., Nippert J.B. et al.: Global diversity of drought tolerance and grassland climate-change resilience. Nat. Clim. Change 3: 63-67, 2013.

Dray S., Dufour A.B.: The ade4 package: implementing the duality diagram for ecologists. - J. Stat. Softw. 22: 1-20, 2007.

D'Antonio C.M., Vitousek P.M.: Biological invasions by exotic grasses, the grass/fire cycle, and global change. - Annu. Rev. Ecol. Syst. 23: 63-87, 1992.

Diez J.M., D'Antonio C.M., Dukes J.S. et al.: Will extreme climatic events facilitate biological invasions? - Front. Ecol. Environ. 10: 249-257, 2012.

Dobson A.P., Bradshaw A.D., Baker J.M.: Hopes for the future: restoration ecology and conservation biology. - Science 277: 515-525, 1997.

Eggemeyer K.D., Awada T., Harvey F.E. et al.: Seasonal changes in depth of water uptake for encroaching trees Juniperus virginiana and Pinus ponderosa and two dominant $\mathrm{C}_{4}$ grasses in a semiarid grassland. - Tree Physiol. 29: 157-169, 2009.

Eggemeyer K.D., Awada T., Wedin D.A. et al.: Ecophysiology of two native invasive woody species and two dominant warmseason grasses in the semiarid grasslands of the Nebraska Sandhills. - Int. J. Plant Sci. 167: 991-999, 2006.

Ehleringer J.R., Field C.B., Lin Z.F., Kuo C.Y.: Leaf carbon isotope and mineral composition in subtropical plants along an irradiance cline. - Oecologia 70: 520-526, 1986.

Ganguli A.C., Engle D.M., Mayer P.M., Hellgren E.C.: Plant community diversity and composition provide little resistance to Juniperus encroachment. - Botany 86: 1416-1426, 2008.

Ganguli A.C., Engle D.M., Mayer P.M., Salo L.F.: Influence of resouce availability on Juniperus virginiana expansion in a forest-prairie ecotone. - Ecosphere 7:e01433, 2016.

Givnish T.J.: Adaptation to sun and shade: A whole-plant perspective. - Aus. J. Plant Physiol. 15: 63-92, 1988.

Hamada S., Kumagai T., Kochi K. et al.: Spatial and temporal variations in photosynthetic capacity of a temperate deciduousevergreen forest. - Trees 30: 1083-1093, 2016.

Helmink S.: Nebraska Forest Service Annual Report. Pp. 10-12. University of Nebraska, Lincoln 2012.

Huxman T.E., Wilcox B.P., Breshears D.D. et al.: Ecohydro- logical implications of woody plant encroachment. - Ecology 86: 308-319, 2005.

Jackson R.B., Banner J.L., Jobbágy E.G. et al.: Ecosystem carbon loss with woody plant invasion of grasslands. - Nature 418: 623-626, 2002.

Kassambara A.: Factoextra: Visualization of the outputs of a multivariate analysis. R package version 1, https://github.com/ kassambara/factoextra, 2015.

Li Y., Awada T., Zhou X. et al.: Mongolian pine plantations enhance soil physico-chemical properties and carbon and nitrogen capacities in semi-arid degraded sandy land in China. - Appl. Soil Ecol. 56: 1-9, 2012.

Liang Z., Drijber R.A., Lee D.J. et al.: A DGGE-cloning method to characterize arbuscular mycorrhizal community structure in soil. - Soil Biol. Biochem. 40: 956-966, 2008.

Liao C., Peng R., Luo Y. et al.: Altered ecosystem carbon and nitrogen cycles by plant invasion: A meta-analysis. - New Phytol. 177: 706-714, 2008.

Liu F., Archer S.R., Gelwick F. et al.: Woody plant encroachment into grasslands: spatial patterns of functional group distribution and community development. - PLOS ONE 8: e84364, 2013.

Long S.P., Bernacchi C.J.: Gas exchange measurements, what can they tell us about the underlying limitations to photosynthesis? Procedures and sources of error. - J. Exp. Bot. 54: 2393-2401, 2003.

McCulley R.L., Jackson R.B.: Conversion of tallgrass prairie to woodland: consequences for carbon and nitrogen cycling. Am. Midl. Nat. 167: 307-321, 2012.

McKinley D.C.: Consequences of Conversion of Native Mesic Grassland to Coniferous Forest on Soil Proceses and Ecosystem C and N storage. Pp. 186. Kansas State University, Manhattan 2007.

McKinley D.C., Blair J.M.: Woody plant encroachment by Juniperus virginiana in a mesic native grassland promotes rapid carbon and nitrogen accrual. - Ecosystems 11: 454-468, 2008.

McKinley D.C., Rice C.W., Blair J.M.: Conversion of grassland to coniferous woodland has limited effects on soil nitrogen cycle processes. - Soil Biol. Biochem. 40: 2627-2633, 2008.

Mellor N.J., Hellerich J., Drijber R. et al.: Changes in ecosystem carbon following afforestation of native sand prairie. - Soil Sci. Soc. Am. J. 77: 1613-1624, 2013.

Miyazawa Y., Kikuzawa K., Otsuki K.: Decrease in the capacity of RuBP carboxylation and regeneration with the progession of cold-induced photoinhibition during winter evergreen broadleaf tree species in a temperate forest. - Funct. Plant Biol. 34: 393-401, 2007.

Muller O., Oguchi R., Hirose T. et al.: The anatomy of a broadleaved evergreen allows an increase in leaf nitrogen content in winter. - Physiol. Plantarum 136: 299-309, 2009.

Nippert J.B., Ocheltree T.W., Orozco G.L. et al.: Evidence of physiological decoupling from grassland ecosystem drivers by an encroaching woody shrub. - PLoS ONE 8: e81630, 2013.

Norris M.D., Blair J.M., Johnson L.C.: Altered ecosystem nitrogen dynamics as a consequence of land cover change in tallgrass prairie. - Am. Midl. Nat. 158: 432-445, 2007.

Norris M.D., Blair J.M., Johnson L.C., McKane R.B.: Assessing changes in biomass, productivity, and $\mathrm{C}$ and $\mathrm{N}$ stores following Juniperus virginiana forest expansion into tallgrass prairie. Can. J. Forest Res. 31: 1940-1946, 2001.

Pacala S.W., Hurtt G.C., Baker D. et al.: Consistent land- and atmosphere-based U.S. carbon sink estimates. - Science 292: 
2316-2320, 2001.

Pardo L.H., Hemond H.F., Montoya J.P., Siccama T.G.: Response of the natural abundance of ${ }^{15} \mathrm{~N}$ in forest soils and foliage to high nitrate loss following clear-cutting. - Can. J. Forest Res. 32: 1126-1136, 2002.

Pierce A.M., Reich P.B.: The effects of eastern red cedar (Juniperus virginiana) invasion and removal on a dry bluff prairie ecosystem. - Biol. Invasions 12: 241-252, 2010.

Rout M.E., Callaway R.M.: An invasive plant paradox. - Science 324: 734-735, 2009.

Sharkey T.D., Bernacchi C.J., Farquhar G.D., Singsaas E.L.: Fitting photosynthetic carbon dioxide response curves for $\mathrm{C}_{3}$ leaves. - Plant Cell Environ. 30: 1035-1040, 2007.

Shinneman D.J., Baker W.L.: Nonequilibrium dynamics between catastrophic disturbances and old-growth forests in ponderosa landscapes of the Black Hills. - Conserv. Biol. 11: 1276-1288, 1997.

Starks P.J., Venuto B.C., Dugas W.A., Kiniry J.: Measurements of canopy interception and transpiration of eastern redcedar grown in open environments. - Environ. Nat. Resour. Res. 4: 103-122, 2014.

Szilagyi J., Harvey F.E., Ayers J.F.: Regional estimation of total recharge to ground water in Nebraska. - Ground Water 43: 6369, 2005.

Throop H.L., Archer S.R., Monger H.C., Waltman S.: When bulk density methods matter: Implications for estimating soil organic carbon pools in rocky soils. - J. Arid Environ. 77: 6671, 2012.

Twidwell D., Rogers W.E., Fuhlendorf S.D. et al.: The rising Great Plains fire campaign: citizens' response to woody plant encroachment. - Front. Ecol. Environ. 11: e64-e71, 2013.

van der Sleen P., Vlam M., Groenendijk P. et al.: ${ }^{15} \mathrm{~N}$ in tree rings as a bio-indicator of changing nitrogen cycling in tropical forests: an evaluation at three sites using two sampling methods. - Front. Plant Sci. 6: 229, 2015.

Volder A., Tjoelker M., Briske D.: Contrasting physiological responsiveness of establishing trees and a $\mathrm{C}_{4}$ grass to rainfall events, intensified summer drought, and warming in oak savanna. - Glob. Change Biol. 16: 3349-3362, 2010.

Walker B.H., Noy-Meir I.: Aspects of the stability and resilience of savanna ecosystems. - Ecol. Stud. 42: 556-590, 1982.

Wilcox B.P.: Transformative ecosystem change and ecohydrology: ushering in a new era for watershed management. Ecohydrology 3: 126-130, 2010.

Williams R.J., Hallgren S.W., Wilson G.W.T., Palmer M.W.: Juniperus virginiana encroachment into upland oak forests alters arbuscular mycorrhizal abundance and litter chemistry. Appl. Soil Ecol. 65: 23-30, 2013.

Willson C.J., Manos P.S., Jackson R.B.: Hydraulic traits are influenced by phylogenetic history in the drought-resistant invasive genus Juniperus (Cupressaceae). - Am. J. Bot. 95: 299-314, 2008.

Wilson K.B., Baldocchi D., Hanson P.J.: Spatial and seasonal variability of photosynthetic parameters and their relationship to leaf nitrogen in a deciduous forest. - Tree Physiol. 20: 565573, 2000.

Yahdjian L., Sala O.E., Havstad K.M.: Rangeland ecosystem services: shifting focus from supply to reconciling supply and demand. - Front. Ecol. Environ. 13: 44-51, 2015.

Zou C.B., Turton D.J., Will R.E. et al.: Alteration of hydrological processes and streamflow with juniper (Juniperus virginiana) encroachment in a mesic grassland catchment. - Hydrol. Process. 28: 6173-6182, 2014. 